\title{
Research of the Henan Private education in regional construction services
}

\author{
Hexiang Lu \\ School of art, Zhengzhou University of Industry Technology, Zhengzhou, 451100, China \\ 517564763 @qq.com
}

\begin{abstract}
The advent of the age of knowledge economy and the development of economic globalization promote the relationship of education and construction of the regional economic more and more closely. With the connotation of "human first, promoting economic cooperation" which Advocate by the Belt and Road, the Private education which combined with its own characteristics and the status quo of the resources to promote culture and education exchange, through cultural Bridges, promote the cooperation between the silk road state, as a cultural structure and have the advantage in cultivate applied talents, the Private education has promote a positive role in regional economic construction. Because of the relationship between private education and regional economic development, the regional economy will surely bring opportunities and challenges for private education, how to maintain and improve the resource advantage of private education to adapt the regional construction has become a problem we must consider.
\end{abstract}

Keywords: private education; regional economy; applied talents; Henan Province.

\section{Introduction}

This paper based on the Private education existing educational resources and advantages and fully with the help of social forces, according to the construction of "double type" teachers team construction and"professional, applying" talent cultivation model " to the fitting degree of school and society and make the students can adapt to the needs of social and economic development better and provide practical and technical personnel for the construction of the regional development in Central Plains Economic Region.

\section{The role of private education in regional development}

The rise of regional economy has become the important point of the world economy, with the advent of the era of knowledge economy, the speeding of regional economic integration became more and more quickly, The way of economic growth to knowledge econom, the rapid development regional economy which depends on talent and technology support cannot leave the education alone, the university is the main body of knowledge creation and knowledge dissemination, as well as the main participants in the technological innovation and knowledge application, many private colleges in henan plays an important role in promoting the economic development in Central Plains Economic Region, ,the development of Private education in henan directly affects the level of economic development in Central Plains Economic Region, the henan private education is the powerhouse in the construction of regional economy in regional construction .

\subsection{The Private education provide personnel support for the regional development}

Colleges and universities is the main cultivation base to provide talents for the regional economic development and the talent is the first resource and core demand of the regional construction. The private colleges of Henan grounding in huanghe river area and the applied talents cultivate is more close to the actual situation of the economic and social development in area and has a easiest way to understand the requirements of local economic and social development in talent and technology, the private colleges has provides advantageous for the development of economy by cultivate practical talents in Central Plains Economic Region. According to statistics by 2016, there are 37 henan non-government college in Henan which have a accurate location and obvious characteristics, 
non-government college cultivate the applied talents with professional characteristics according to different industry, the school also adjustment the setting of subjects to adapt to the demand of regional economic structure adjustment,industrial upgrading and social development to each kind of talented person's.

\subsection{The Private education provide technology support for regional economic development}

From the current situation, the Central Plains Economic Region enterprise's technology development ability is weak, it is difficult to undertake major involved in basic research and technological innovation projects while private colleges has gathered a large number of technical professional with strong practical ability and scientific research ability in different areas, at the same time, the school has complete laboratory facilities and engineering research center, if the cooperation between enterprises and private colleges and provide a good environment and powerful funds safeguard for universities and scientific research personnel,this way can attract the technical personnel focus on the development of regional economy and carry out academic research, actively involved in the policies of the central plains and the technical development to promote the development of regional economy.

\subsection{The Private education is the leader of regional innovation culture}

The regional economic development is need ed both material civilization and spiritual civilizationPrivate colleges profound culture and perfect infrastructure construction, the spirit of innovation ,open and free academic atmosphere can continue to inspire new ideas, new knowledge and new technology. As a local science and cultural center In the construction of regional, private colleges can not only provide direct intellectual support for regional development but also play a leading role in rich cultural connotation, strong cultural atmosphere, shaping the humanities spirit and promote regional innovation culture environment construction.

\section{The opportunities and challenges in regional construction of henan Private education}

Private education has a great influence on the regional economic development, but on the other hand, the development of education is restricted by the level of economic development, especially the restriction of the regional economy, raising the level of economic development to improve the education conditions, optimize education resources, and improve the quality of education.

\subsection{The regional economic development level affect investment of private education}

Regional economic and social development level will affect the local fiscal revenue which affects the investment of private education. Expenditure on education is an important component of fiscal expenditure, private education development needs the support of local government financial, the more the economy development, the more abundant local fiscal revenue which the government can investment education betterly.

\subsection{The regional economic development level influence the employment of private education}

Employment is a derived demand, henan university students' employment situation is determined by the industrial structure and economic structurein Central Plains Economic Region and promote upgrading of the industry is an important content of national five-year plan, through promote upgrading of the industrial structure to promote the national economy turn from extensive growth to the connotative growth change, it's requires a large number of outstanding technical and management talents for change the way of economic growth, it will be able to solve the employment problem of graduates.

\subsection{The development level of regional economic influence the speed of the development of private education}

The development of regional economy, make the improvement of people's living standards,then the material civilization reaches a certain degree and inevitably produce the pressing needs of receiving higher education, the increase in demand also indirectly stimulate private colleges need to expand the scale of school, at the same time improve the quality of teaching and increase the subject 
setting in order to meet the demand of the general public, it also indirectly promoted the development of private higher education popularization and gradually formed its own characteristics.

\section{The problems and measures of henan regional private education service construction}

Although henan Private education made great contribution to the development of regional economy, but in recent years, private colleges educational philosophy is changed along with the student enrollment expansion and the evaluation of higher education for country, talents cultivation, scientific research and social service are the three major functions of higher education, henan Private education must change its inherent thought, from simply transfer knowledge institutions into important agency service for the society.

4.1 The problems of private education in the construction of regional service

4.1.1 Private education school-running orientation is not accurate

In recent years, as students enrollment, some colleges and universitieshas a wrong orientation in henan province,make the private colleges educational to bacame comprehensive university or cu university not only lost the school characteristics and advantagesbut also can cause separate between teaching and employment, it is bad to the service of regional construction and affect the sustainable development of the school itself.

\subsubsection{Scientific research and transformation mechanism is not sound}

Henan Private education or scientific research institution can really do the service for local economic and social development,by transform the academic research to the first productivity in reality, and then promote the economic developmentin Central Plains Economic Region .

\subsection{The countermeasures of Henan Private education service for the regional economic and} social development

\subsubsection{The private education must service place}

The relationship between regional economy and Private education is support each other and the production department of regional economy is the main job market of local college graduates, with the progress of the society, the talent demand shows the characteristics of marketization that demand for talent in economic construction has obvious regional characteristics, so the private colleges should strengthen the concept of service for the regional economic development and should be based on local economic development needs in scientific research or in the cultivation of talents, adjust the orientation of the school and highlight the school characteristics, optimize professional Settings, perfect the teaching plan, at the same time pay attention to combining theory teaching and practice teaching, for the economic developmentin Central Plains Economic Region.

\subsubsection{Improve the mechanism of transformation of scientific research}

The Private education administration department should pay more attention to conver scientific research work into the first productive force, and improve the mechanism of the private education scientific research into the central plains. For example, to create a platform for transformation of scientific research achievements, encourage private education to strengthen the link of the enterprise, in this platform, Private education and the enterprise joint research technology projects, risk-sharing, benefit sharing, at the same time..

The scientific research management of private education institutions is a bridge between colleges and enterprises, therefore, the university scientific research management institutions should work completes the conversion of scientific research platform, actively adapt to market demand and operation mechanism of transformation of scientific research and provide guarantee system for scientific research, makes Private education services for the construction of regional technical service.

\section{Summary}

The relationship of Henan Private Education and regional economy is mutual benefit and restriction. Private colleges and universities is the cradle of knowledge production and 
dissemination, it has become a motive force of the economic development and important platform and carrier of scientific research achievements into productivity. In the process of service for the construction of regional, henan Private education plays a leading and supporting role, enhance the level of private education services regional economic is not only a mission of Private education, At the same time, the regional economic development will also bring new opportunities and challenges to the private education, thus to promote the better development of private education itself.

Although private education play an important role in the regional construction, but the private education also appeared some problems in the process of serving local economic development, how to take measures to maintain and improve the resource advantage of private education adapt to the regional construction is a problem we must solve.

\section{References}

[1] Rui Na Guan, Feng Li. Discussion on the social functions of the private university. Chinese University Technology Transfer. 2009, No.3, p. 13-116.

[2] YingJia Zhou, The practice and exploration of local economic and social development in private colleges and Universities. Journal of Xiangfan University. 2009, No. 8, p. 218-219. 